\title{
Investigation Effect of Free Radical Generated from Cement Dust on Antioxidant Enzymes Activities on Cement Factory Workers
}

Friday $\mathrm{ET}^{1 *}$, Alabi OJ ${ }^{2}$ and Akpa $\mathrm{M}^{3}$

${ }^{1}$ Medical Biochemistry, Kogi State University, Nigeria

2Department of Community medicine, kogi state university, Nigeria

${ }^{3}$ Deptartment of Obstetrics and Gynaecology, kogi State university anyigba, Nigeria

\section{Research Article}

Volume 1 Issue 1

Received Date: September 04, 2016

Published Date: September 10, 2016

*Corresponding author: Emmanuel Titus Friday, Medical Biochemistry, College of Health Sciences, Kogi State University, Anyigba, Nigeria, E-mail: emmfriday@gmail.com

\section{Abstract}

This study investigated effects of cement dust on antioxidant enzymes activities of Obajana Cement factory workers. Sixty (60) workers in different units/sections exposed to cement dust and controls (unexposed to cement dust) were used for this study. Colorimetric method was used to analyze superoxide dismutase and catalase. The results showed that the oxidative stress indices showed that superoxide dismutase (SOD) and catalase (CAT) activities were significantly higher $(p<0.05)$ in the exposed worker as compared to control. SOD and CAT in the exposed workers were significantly increased in aged and long term duration of exposure of workers to cement dust. In this study the increased activity of these enzymes in workers working in cement dust area is an indication of effect of cement dust on human health. Therefore a program for prevention of the impact of such exposure to workers should be put in place.

Keywords: Antioxidant enzymes; Superoxide dismutase; Catalase; Exposed and Unexposed Workers

\section{Introduction}

Most common air pollutants are known to produce free radicals either inside or in close proximity to cells [1]. Cement factories are considered as a major pollution problem because of dust and particulate matter emitted at various steps of cement production [2]. Vencent Castranova (1994) reported that the free silica stimulates neutrophils by activating the respiratory burst to produce superoxide anion $\mathrm{O}_{2}^{-}$and hydrogen peroxide $\left(\mathrm{H}_{2} \mathrm{O}_{2}\right)$ which are now known to be implicated in a large number of human and animal diseases. In some conditions, they play a significant role in the disease itself.
Occupational cement dust exposure has been associated with an increase risk of liver abnormalities, pulmonary disorders and carcinogenesis [3]. Some of these abnormalities or disorders are consequent of free radical generated from dust or particulate.

Free radicals are formed in greater amounts during almost all human diseases, that is some degree of oxidative stress probably occurs in all diseases. This does not mean that free radicals cause disease or that they contribute significantly to its course [4]. The production 


\section{International Journal of Biochemistry \& Physiology}

of free radicals has been postulated in the pathophysiology of many of the inflammatory reactions that ultimately cause fibrosis and scarring [5,6].

The production of free radicals, or factors possessing properties of free radicals, occurs during the activity of various oxidative enzymes. These radicals appear to play important roles in biological oxidation involving one electron transfer.

At normal rates of generation, some free radicals are useful in the human body. However, when free-radicals generation exceeds the capacity of antioxidant defenses, the result is oxidative stress. Oxidative stress occurs in many human diseases and sometimes makes a significant contribution to their pathogenesis [7].

Superoxide dismutase is a dimeric enzyme present in the cytosol of all mammalian cells [8] and may be found in extracellular fluids. One physiological role of extracellular superoxide dismutase is located on substances as heparin sulphate and other sulphated glucosaminoglycan on cell membranes and in connective tissues, therefore its role is probably to protect cell surfaces from superoxide by binding to heparin sulphate, proteoglycans in the glycocalyx of the cells and in the interstitial matrix. The biological function of SOD is to catalyze removal of $\mathrm{O}_{2}$ radicals. The superoxide theory of $\mathrm{O}_{2}$ Toxicity has been given by the accumulation of evidence showing that superoxide dismutase (SOD) enzymes, which remove $\mathrm{O}_{2}$ by accelerating the dismutation reaction, are of great importance in allowing organisms to survive in the presence of $\mathrm{O}_{2}$ and to tolerate increased $\mathrm{O}_{2}$ concentrations [9].

Catalase is one of the antioxidant that decomposes hydrogen peroxide to molecular oxygen and water and is located in a cellular bipolar environment organelle called peroxisome [10]. It protects cells from the toxic effects of hydrogen peroxide. It consists of four subunits; each subunit has a molecular mass of 6000 and contains a hematin group as its prosthetic group. It is a common enzyme found in nearly all living organisms exposed to oxygen. It is a very important enzyme in protecting the cell from oxidative damage by reactive oxygen species (ROS) and has one of the highest turnover numbers of all enzymes; one molecule of catalase can convert millions of molecules of hydrogen peroxide to water and oxygen each second. All known animals use catalase in every organ with particular high concentration occurring in the liver. Catalase is also universal among plants and many fungi are also high producers of enzyme. Almost all aerobic microorganisms use catalase. It is also present in some anaerobic microorganisms such as methanosarcina [11].

Under normal circumstances, as a response to oxidation process, the body utilizes scavenging antioxidant enzymes such as ceruloplasmin (CP), superoxide dismutase (SOD), and glutathione peroxidase [12], to protect from such damage by a careful balance between pro-oxidants and antioxidants. This study is aim at evaluating the consequence of effect of cement dust on SOD and CAT activities of cement factory workers.

\section{Material and Methods}

\section{Materials}

Chemicals and Reagents: All chemicals and reagents were of analytical standard.

\section{Sample Collection}

Blood samples: Five milliliters $(5.0 \mathrm{ml})$ of blood samples were collected from 60 factory workers from different sections/units (randomly selected) through the clinic (10 samples from each section: quarry dust workers ,milling, kiln, bagging, loading bay workers, and 10 from non workers as control). Blood samples collection were carried out by medical personnel in clinic Lokoja, Kogi state, Nigeria following and informed consent by the workers.

The workers in these sections were selected because of their high level of exposure. Fifty eligible subjects working in these sections were enrolled in the study. They had been exposed to cement dust for 2 to 10 years. An unexposed (control) group consisted of 10 blue-collar workers who are matched by socio-economic class and age with the exposed group. The unexposed groups are workers and reside 20 kilometers away from the cement factory in the Obajana. Only subjects who are non smokers and who had no history or signs suggestive of respiratory, haematologic, bone or liver diseases were eligible and selected into both the exposed and unexposed groups. However individuals with symptoms common among workers performing dusty operations such as cough and sneezing were not enrolled into either group.

\section{Ethical clearance}

Ethical clearance was dully obtained from Department of Research and Development. Ministry of Health, Lokoja, Nigeria. Written and verbal informed consents were taken from all workers. 


\section{International Journal of Biochemistry \& Physiology}

\section{Anthropometric Parameters Questionnaires}

Anthrometric parameters: These were done according to the method described by Manjula et al. 2013. Data were collected by general demographic profile; smoking, clinical signs, medical/clinical history. With the help of pre designed questionnaires by personal interview method and clinical examination. The weight and height were taken with standometer. The information regarding the use of personal protection equipment, work coverall, gloves, dust masks, earplugs and safety hood, years of exposure as deduced from date of employment, site or position at workplace, use of safety gadgets such as dust masks and earplugs, general health, history of past disease(s) and habits such as smoking and alcohol consumption were obtained (13).

\section{Analyses}

\section{Determination of Superoxide Dismutase (SOD)}

Principle: Superoxide dismutase estimation was based on the ability of SOD to inhibit the autoxidation of Epinephrine at PH 10.2 (14).

Procedure: Exact $0.5 \mathrm{ml}$ of Epinephrine( $3 \times 10^{-4} \mathrm{M}$ Epinephrine (Sigma) $10 \mathrm{mg} / 500 \mathrm{ml} \mathrm{pH} \mathrm{2)} \mathrm{was} \mathrm{added} \mathrm{to}$ $0.5 \mathrm{ml}$ sodium carbonate $(0.05 \mathrm{M}$ Sodium carbonate $5.3 \mathrm{gm} / \mathrm{L} \mathrm{pH} 10.2)$ and $0.5 \mathrm{ml} \operatorname{EDTA}\left(1 \times 10^{-4} \mathrm{M}\right.$ EDTA $40 \mathrm{Mg} / \mathrm{L} \mathrm{pH} \mathrm{10.2).At} 480 \mathrm{~nm}$ the rate of increase of absorption per minute was measured. The reaction was done after addition of $100 \mu$ l plasma. The ability of SOD to inhibit the autoxidation of Epinephrine to produce adrenochrome at $\mathrm{pH} 10.2$ was determined.

The absorbance change was $0.025 /$ minute and 50\% inhibition was achieved by $46 \mathrm{ug} / \mathrm{ml}$ of SOD.

Determination of Catalase: Catalase activity was determined according to the method of Sinha (15)

\section{Principle}

This method was based on the reduction of dichromate in acetic acid to chromic acetate when heated in the presence of $\mathrm{H}_{2} \mathrm{O}_{2}$ with the formation of perchromic acid as unstable intermediate.

The chromic acetate so produced is measured colorimetrically at $570-610 \mathrm{~nm}$. It must be noted that dichromate has no absorbance at the wavelength and its presence in the assay mixture does not interfere with the determination. Catalase preparation (in samples) is allowed to split $\mathrm{H}_{2} \mathrm{O}_{2}$ for different period of time. The reaction is stopped at a particular time by the addition of dichromate/acetic acid mixture and the remaining $\mathrm{H}_{2} \mathrm{O}_{2}$ is determined by measuring chromic acetate colorimetrically after heating the reaction mixtures.

\section{Statistical Analysis}

All data were expressed as mean \pm SEM and Graph Pad Instat - [DataSet 1.ISD] was applied to determine the significance of the difference at $\mathrm{P}<0.05$

\section{Results}

\section{Anthropemetric Parameters of Workers Exposed and Unexposed to Cement Dust}

Our results in table 1 show a summary of the age, height, body weight and hour of exposure distribution in exposed cement workers, [Crusher workers (CW), Kiln workers (KW), Milling workers (MW), Bagging workers (BW) and Loading workers (LW)] and non exposed workers of different Units/Department of Obajana Cement Factory. The two groups) exposed and unexposed workers) were similar in most of the anthropometric parameters measured.

\begin{tabular}{|c|c|c|c|c|c|}
\hline Section/unit & AV.Height (m) & AV.Weight (g) & Age range (yr) & expose hr/daily & year of expos(yr) \\
\hline Cw & $1.61 \pm 0.06$ & $66.26 \pm 6.02$ & $22-55$ & $8.00 \pm 0.00$ & $6.30 \pm 2.15$ \\
\hline Kw & $1.63 \pm 0.05$ & $63.86 \pm 7.67$ & $22-55$ & $8.80 \pm 2.53$ & $4.50 \pm 1.29$ \\
\hline Mw & $1.60 \pm 0.04$ & $64.04 \pm 6.06$ & $22-55$ & $10.00 \pm 2.11$ & $4.26 \pm 1.49$ \\
\hline Bw & $1.63 \pm 0.05$ & $64.44 \pm 4.30$ & $22-55$ & $9.60 \pm 3.73$ & $5.70 \pm 1.85$ \\
\hline Lw & $1.62 \pm 0.04$ & $65.01 \pm 4.58$ & $22-55$ & $9.60 \pm 3.37$ & $5.70 \pm 1.85$ \\
\hline CONTROL & $1.65 \pm 0.04$ & $64.69 \pm 9.03$ & $22-55$ & $0.00 \pm 0.00$ & $0.00 \pm 0.00$ \\
\hline
\end{tabular}

Table 1: Anthropometric Parameter of Exposed and Control Subjects.

Key Note: CW= Crusher worker in the factory unit, KW = Kiln workers, MW =milling workers, BW = bagging workers, LW $=$ loading workers and CONTROL $=$ subject far away from factory, $\mathrm{AV}=$ average. 


\section{International Journal of Biochemistry \& Physiology}

The result showed height distribution (mean + SD) in units $1.61-1.63 \pm 0.05 \mathrm{~m}$, Body weight range between $63.86 \pm 7.67-66.26 \pm 6.02 \mathrm{~kg}$ body weight, Age ranged between $22-55$ years. Year in the work range $4.26 \pm 1.49$ $-6.30 \pm 2.15$ years and hour of exposure ranged between $8.0 \pm 0.00$ to $10.00 \pm 2.11$ hours daily of the workers were exposure to dust. The use of masks as a personal protective device was $65 \%$, most of the workers were using them intermittently. It was also revealed from the questionnaire that the use of apron among the workers was put at average of $40-60 \%$.

Antioxidant Enzymes Activities in Exposed and Unexposed Workers to Cement Dust

Figures 1 to 6 showed the superoxide dismutase, catalase activities in workers exposed to cement dust in Obajana cement factory.

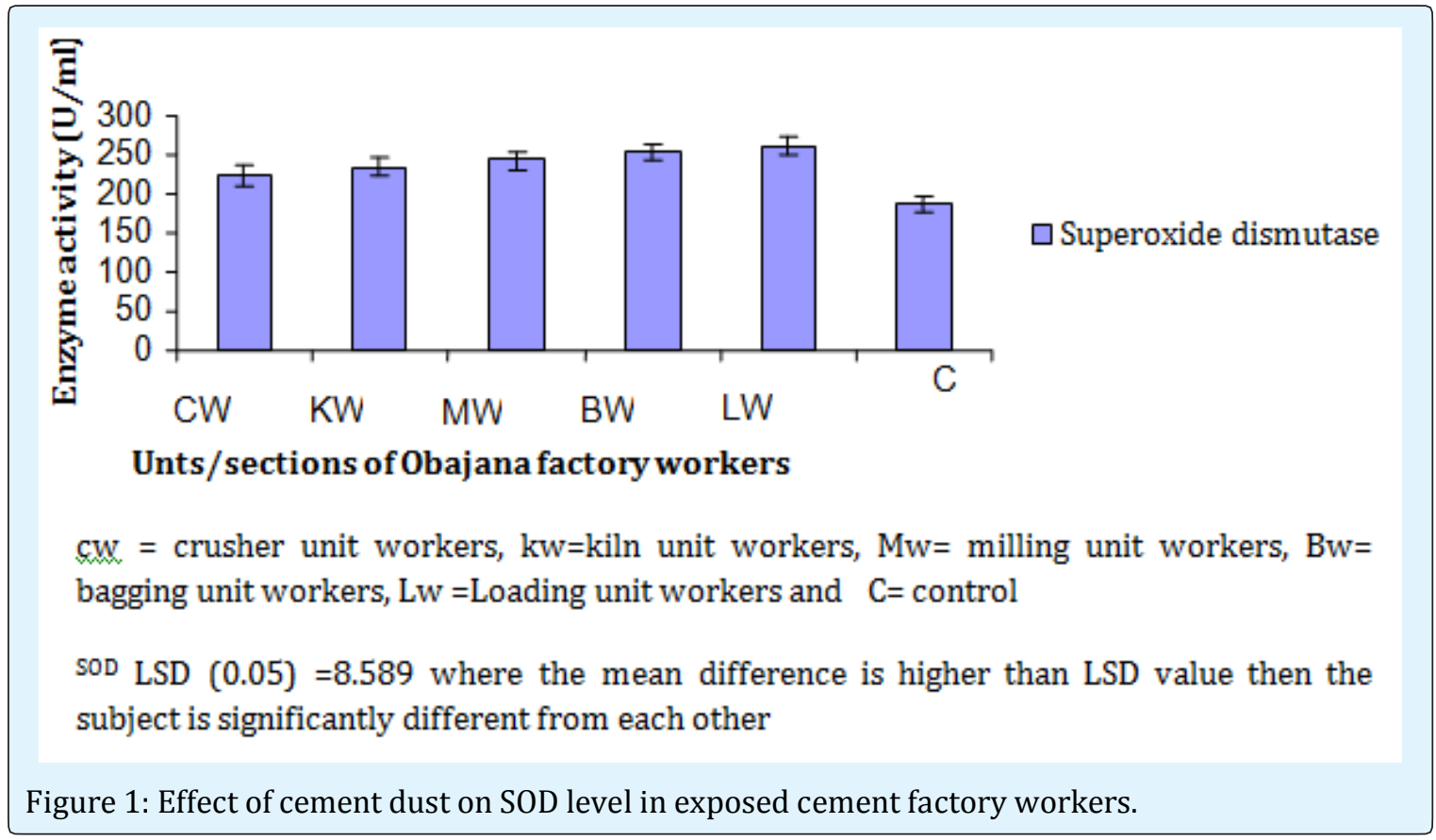

The values of SOD was statistically different from the control, that this the values were higher than LSD indication continue exposure to cement dust showed more effect on the enzyme activity

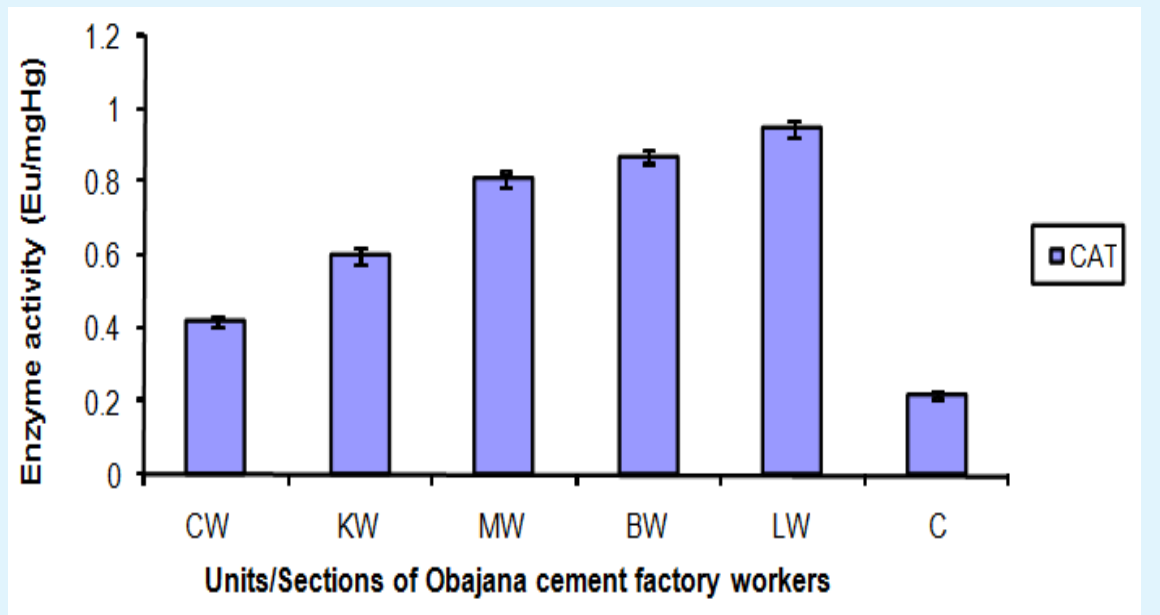

Figure 2: Catalase activity in worker exposed to cement dust. 


\section{International Journal of Biochemistry \& Physiology}

CATLSD $(0.05)=0.062$ where the mean difference is higher than LSD value then the subject is significantly difference from each other.
The results showed the activity of CAT significantly higher exposed workers with working in the LW was more affected.

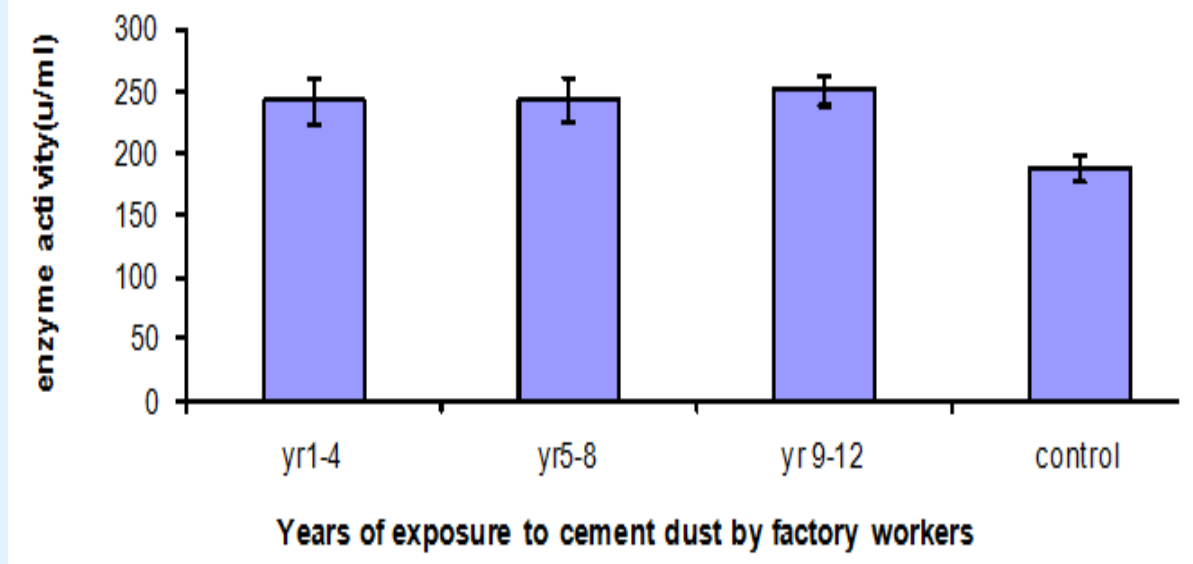

Figure 3: Effect of cement dust on SOD level on cement factory workers in relation to year of exposure.

SODLSD $(0.05)=7.730$ (where the mean difference is higher than LSD value then the subject is significantly difference from each other).

In SOD workers exposed for period of years have high activity compared to control. Workers exposed for period of 9 - 12 years have higher value and little difference observed between workers exposed for $5-8$ and $1-4$ years.

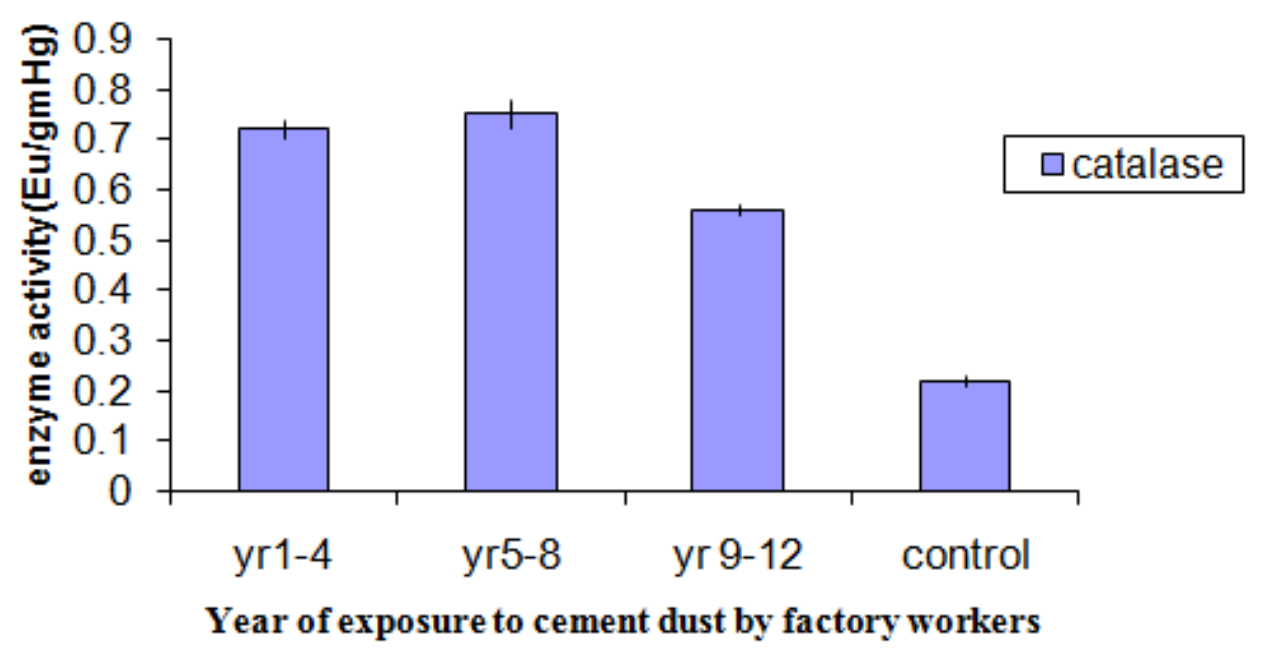

Figure 4: Effect of cement dust on level of catalase enzyme in workers in relation to period of exposure. 


\section{International Journal of Biochemistry \& Physiology}

CATLSD $(0.05)=0.117$ (where the mean difference is higher than LSD value then the subject is significantly difference from each other).

\section{Effect of Cement Dust on Oxidative Stress in Exposed and Unexposed Workers (Control) in Relation to Age}

While CAT value was higher in $5-8,1-4$ and $9-12$ years of exposure in this order.

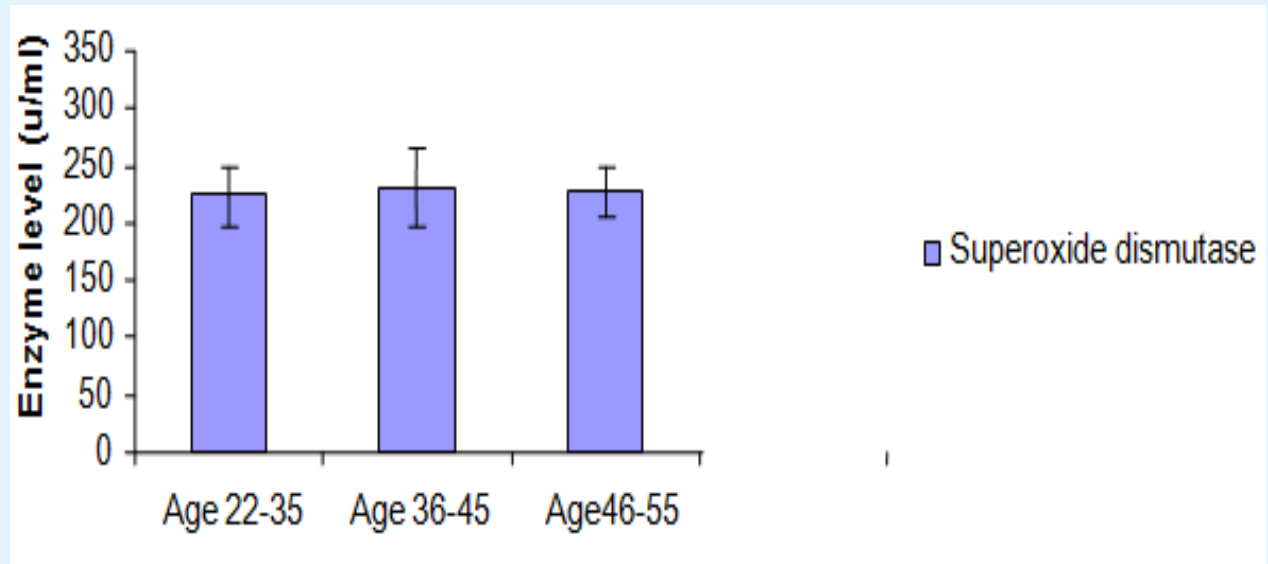

\section{Age range of Obajana cement factory workers}

Figure 5: Superoxide dismutase activity in workers exposed to cement dust in relation to their age.

SODLSD $(0.05)=7.390$ (where the mean difference is higher than LSD value then the subject is significantly difference from each other).
The result did not show significant difference among the group age.

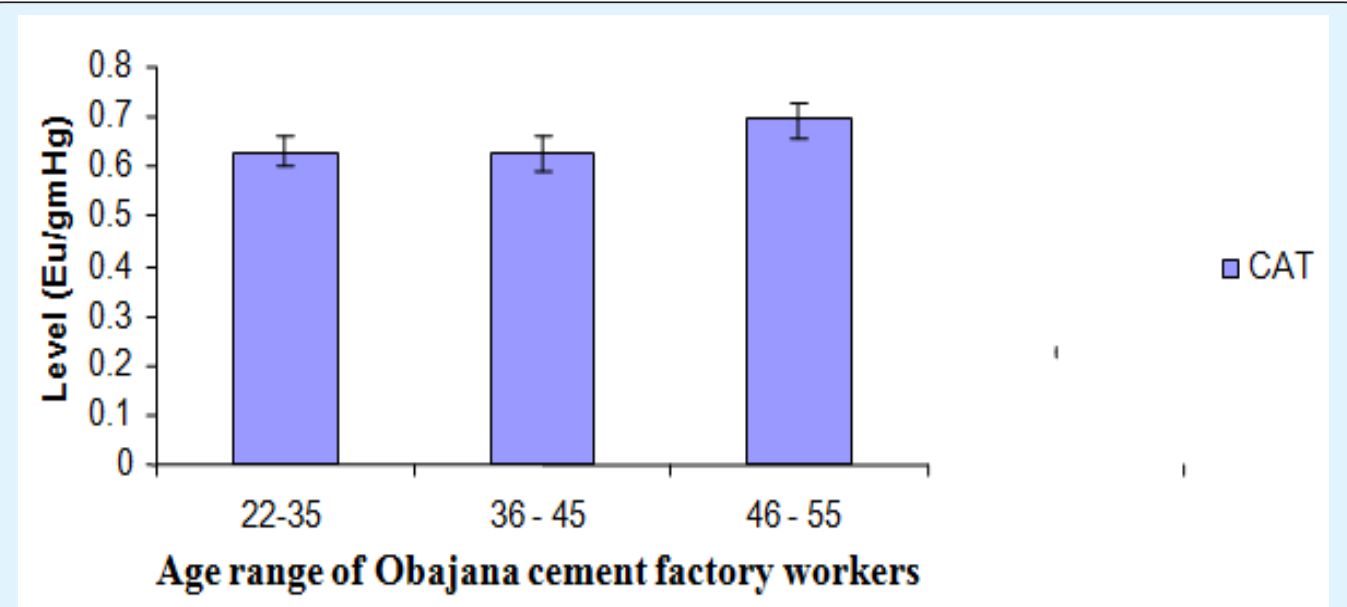

Figure 6: Effect of cement dust on catalase level in factory workers in relation to age. 


\section{International Journal of Biochemistry \& Physiology}

CATLSD $(0.05)=0.040$ (where the mean difference is higher than LSD value then the subject is significantly difference from each other).

The result showed that the catalase enzyme activity was raised in workers in age ranged 46-55 years old compared to other peer groups.

\section{Discussion}

The oxygen free radical superoxide (0-2) is an anion radical produced if oxygen $\mathrm{O}_{2}$ accepts only one electron. It is a moderately aggressive molecule. If $0-2$ accepts two electrons, hydrogen peroxide $\mathrm{H}_{2} \mathrm{O}_{2}$ is formed. Both $0-2$ and $\mathrm{H}_{2} \mathrm{O}_{2}$ are produce during normal metabolism and perform several useful functions. But excessive production of $0-2$ and $\mathrm{H}_{2} \mathrm{O}_{2}$ can result in tissue damage, which often involves generation of highly reactive hydroxyl radical $(\mathrm{OH})$ and other oxidants in the presence of catalytic iron or copper ions (9). Different enzymatic and non-enzymatic antioxidants are available to deal with different types of radicals under a variety of conditions. The enzymatic antioxidants eliminates the first two reduction stages of oxygen and include superoxide dismutase (SOD) which dissimulates $0-2$ and glutathione peroxidase and catalase which destroy $\mathrm{H}_{2} \mathrm{O}_{2}(9)$.

The findings as showed in the results indicated values of SOD and CAT activity were increased in the exposed workers than the unexposed. With the same manner statistical evaluation demonstrated a significant variation at $\mathrm{p}<0.05$ when compared with those unexposed workers. Increased activity of the antioxidant enzymes and depletion of total antioxidant capacity may increase the susceptibility of patients to oxidative injury (16). The increased in SOD levels of cement workers plasma as indicated in the result might be due to the fact that exposure to air polluted by cement dust which generates an increase in the production of reactive oxygen species especially superoxide anion. The superoxide radical produced is neutralized by SOD and the decrease in the activity of this antioxidant reveals that exposure to cement dust leads to increased oxidative stress (17).

The comparisons among workers exposed to cement dust in each unit/sections of the cement factory showed no significant different ( $p>0.05)$. These findings imply that cement dust cause oxidative stress which is deleterious to the human health. Because reactive Oxygen species (ROS) such as singlet Oxygen $\left(\mathrm{O}_{2}\right)$ hydrogen peroxide $\left(\mathrm{H}_{2} \mathrm{O}_{2}\right)$,superoxide anion $\left(\mathrm{O}_{2}\right)$ and hydroxyl radical $\mathrm{OH}$ are generated as byproducts of biological reactions or exogenous factor will be increased. And this may lead to diseases caused by involvement of these species which include rheumatoid arthritis, atherosclerosis, skin aging, nephritis, reperfusion injury, asthma, diabetes mellitus and carcinogenesis $(1,18,19)$.

The result further indicated that the exposure to cement dust increases CAT activity. It is generally believed that hydrogen peroxide can be detoxified by CAT, which removes it when CAT is present at a high concentration (20). A reduction in the level of these enzymes may render the liver more susceptible to hydrogen peroxide induced oxidative stress. Moreover, single oxygen and peroxyl radicals can inhibit SOD and CAT activities. Enzymes that scavenge oxygen free radicals like CAT and SOD decreased by 50\% upon pollutant exposure (17).

Increased in these enzymes activity in the cement workers has showed in the results hypothesis that cement dust leads to a greater oxidative burden and depletion of the antioxidant defense system.

The health risks posed by inhaled dust particles influenced by the duration of exposure and biological responses exerted by the particle (21).

Increase year of exposure to cement dust have significant different in superoxide dismutase and catalase activities in the workers exposed to cement dust as years increases compared to control. This may be attributed to the reduced cellular defence mechanisms due to old age or cytochrome b5 reductase deficiency or pyruvate kinase deficiency as reported by Manassaram, 2006.

However, the superoxide dismutase and catalase activities significantly higher $(\mathrm{p}<0.05)$ in aged $22-35$ and 36 - 45 years compared to age 46 and above. This showed that the age of workers below 46 years may likely generate ROS which requires high level of antioxidant to neutralised the effect compared to the workers with age 46 years and above. This is in line with the report of Goth, 1991 that say serum catalase increased with age.

\section{Conclusion}

This study was conducted to investigate the SOD and CAT of effect of cement dust on Obajana cement factory workers.

About 60 workers were selected from different units/sections of the factory namely: crusher, kiln, milling, bagging, and loading unit. Questionnaires were administered to obtained anthropometric parameters, socio - economic and health status of the participants The anti oxidants determined include superoxide dismutase 


\section{International Journal of Biochemistry \& Physiology}

(SOD), catalase (CAT) in blood sample of the workers in different unit/sections of the factory: crusher worker $(\mathrm{CW})$, kiln workers (KW), milling worker (MW), bagging workers (BW) and Loading workers (LW) using standard method. Analysis of variance (ANOVA) was used to analysed the data obtained while Least Significant Difference (LSD) at 0.05 was used separate the different between the means.

The results showed that SOD, and CAT enzymes activities were significantly raised in workers exposed to cement (i.e CW, KW, MW, BW and LW) compared to control (unexposed workers), workers in BW and LW were more affected. SOD and CAT were significantly increased with increased in period of exposure and age of workers exposed to cement dust. With these findings this study adds to evidence that cement dust adversely affect oxidative stress activity and also impairment is associated with duration of exposure to cement dust. The findings are of importance in that it highlights the need to overcome the effects of long-term exposure. It also exhibits the magnitude of the effect in a population.

Alteration of antioxidants activity in workers exposed to cement dust is an indication of the deleterious effect of cement dust on human health. Therefore, it is advisable that the cement factory management, their workers, and heaths officials even Government should work together to adopt technical preventive measures such as a well ventilated work areas, workers should wear appropriate apparel, mask, safety goggles, gloves, ear plugs, provide period medical surveillance test. Heath education should be given regarding the personal protection measures, and needs reinforcement in form of regular education programs and legislative.

\section{References}

1. Florence TM (1995) The role of free radicals in disease. AUST-NZJ Ophthamology 23(1): 3-7.

2. Ogunbileje JO, Akinosun OM, Anetor JI, Akinduti PA, Ejilude 0, et al. (2010) Effects of Different Cement Factory Sections Products On Immunoglobulin Levels And Some Biochemical Parameters In Nigeria Cement Factory Workers. New York Science Journal 3(12): 102-106.

3. Vijai SS, Deep NP (2011) Human Health Risk due to Cement Dust Exposure. Jaipur RSPCB policy Brief 2.
4. Halliwell B, Gutteridge JMC eds. (1995) Antioxidants innutrition, health and disease. Oxford University Press, US, pp.1-143.

5. Halliwell, B. and Gutteridge, J.M.C. (1989) Free Radicals in Biology and Medicine ( $\left.2^{\text {nd }} e d n\right)$ Clarendon Press, Oxford.

6. Bleasdale C, Butcher G, Jackson MJ, Evans CC, Hind CRK (1990) Circulating concentrations of free radical activity in patients with cryptogenic fibrosing alveolitis. Thorax 45: 784 .

7. Yoshikawa $T$ (1993) Free Radicals and their scavengers inparkinson's Disease. Eur Neurol 33 (Suppl I): 60-68.

8. Marklund SL, Westman NG, Lundgren E, Roos G (1982) Copper and Zinc containing superoxide dismutase manganese containing superoxide dismutase catalase and glutathione peroxidase in normal and neoplastic human cell lines and normal human tissues. Cancer Res 42(5): 1955-1961.

9. Halliwell B (1994) Free radicals, antioxidants and human disease: Curiosity Cause or consequence? Journal of Lancet 344(8924): 721-724.

10. Alberts B, Johnson A, Lewis J, Raff M, Roberts K, et al. (2002) Peroxisomes molecular Biology of cell (4th ed.) New York, Garland Science.

11. Brioukhanov AL, Netrusov AI, Eggen RI (2006) The catalase and superoxide dismutase genes are transcriptionally up regulated upon oxidative stress in the strictly anaerobic archaeon methanosarcina barkeri. Journal of microbiology 152(6): 1671-1677.

12. Rasha HJ, Ali WN, Shade MH (2012) Evaluation of oxidative stress and liver function parameters in the sera samples of Kufa cement factory workers. Journal of Kufa for chemical science Vol. no 5.

13. Emmanuel TF, Okaka ANC, Ibiam UA, Alabi O (2015) Effects of cement dust on heamatological parameters in Obajana cement factory workers. European Scientific Journal vol.11, No.27.

14. Misra HP, Fridovich I (1972) The role of superoxide anion in autoxidation of epinephrine and simple assay for superoxide dismutase. Journal of biol chem 247(10): 3170-3175. 


\section{International Journal of Biochemistry \& Physiology}

15. Sinha AK (1972) Colometric Assay of Catalase. Analytical Biochemistry 47(2):389-394.

16. West IC (2000) Radicals and oxidative stress in diabetes. Journal of Diabetic Medicine 17(3):171-180.

17. Khan SM, Sobti RC, Kataria L (2005) Pesticides induced alteration in mice hepato oxidative status and protective effects of black tea extract. Clinical chemistry Acta 358(1-2): 131-138.

18. Steinberg D, Parthasarathy S, Caraew TE, Khoo JC, Witztum JL (1989) Beyond cholesterol. Modification of low-density lipoproteins that increases its artherogenicity. New Eng Journal of Medicine 320(14): 915-924.

19. Stadtman ER, Oliver CN (1991) Metals ion-catalyzed oxidation of proteins, physiological consequences. Journal of Biology Chemistry 266(4): 2005-2008.
20. Casado A, Dela TR, Lopez-Fermandez M, Carrascosa D, Casado MC, et al. (1995) Superoxide dismutase and catalase blood levels in patients with malignant diseases. Journal of Cancer lett 93(2): 187-192.

21. Meo SA, Azeem MA, Ghori MG, Subhan MM (2002) Lung function and surface electronmyography of intereostal musles in cement mill workers. Inernational Journal of occupational Medicine and Environmental Health 15(3): 279-287.

22. Chaturvedi UC, Shrivastava R, Upreti RK (2004) Viral infections and trace elements: A complex interaction. Journal of current science 87(11).

23. Manassaram DM, Backer LC, Messing R, Fleming LE, Luke B, et al. (2010) Nitrates in drinking water and methaemoglobin levels in pregnancy: A longitudinal study. journal of environmental health 9: 60 . 